\title{
Role of predatory infauna in structuring marine soft-bottom communities
}

\author{
William G. Ambrose, Jr.* \\ University of North Carolina at Chapel Hill, Curriculum in Marine Sciences, Chapel Hill, North Carolina 27514 \\ and Institute of Marine Sciences, Morehead City, North Carolina 28557, USA
}

\begin{abstract}
Present characterizations of interactions in marine soft-bottom communities classify fishes, crabs and birds (epibenthic predators) as predators, and infaunal species as prey. Many infaunal species, however, are themselves predators and -. as prey for epibenthic predators and predators on other infauna - may function as intermediate predators. Data from 7 studies which employed cages to exclude epibenthic predators were used to test the hypothesis that predatory infauna do not become proportionally more abundant following exclusion of epibenthic predators. Predatory infauna became proportionally more abundant after epibenthic predators were excluded from muddy-sand and seagrass habitats. This increase could be a consequence of preferential predation on predatory infauna by epibenthic predators, preferential predation on predatory infauna and predation by predatory infauna on other infauna, or equal predation on all infauna with additional predation by predatory infauna on other infauna. The result suggests that predatory infauna should be considered separatly from nonpredatory infauna when modeling interactions in soft-bottom communities and allows the prediction that prey species of predatory infauna may be less abundant in the absence than in the presence of epibenthic predators
\end{abstract}

\section{INTRODUCTION}

Previous studies of marine soft-bottom community structure indicate that predation and/or disturbance by large, mobile epibenthic predators (such as bottomfeeding fishes, crabs and birds) are often important regulators of species abundance. Caging studies that exclude these predators from portions of the unvegetated bottom frequently result in large increases in the density of benthic infauna (see review by Peterson, 1979). As a result, our present characterization of interactions in these soft-bottom communities classifies fishes, crabs and birds as predators and infaunal species as prey. Many of the infauna, however, are themselves predators (e. g. nemertean and polychaete worms) and these groups also increase in the absence of epibenthic predators (Reise, 1977, 1978; Lee, 1978; Holland et al., 1980). These predatory infauna are capable of influencing the abundances of other infaunal species (Roe, 1976; Reise, 1979; Ambrose,

\footnotetext{
- Present address: Institute of Marine Biology and Limnology, Department of Marine Zoology and Marine Chemistry, University of Oslo, Oslo, Norway
}

1982; Commito, 1982; Oliver et al., 1982). Expanding our present characterization of soft-bottom community structure by separating predatory and non-predatory infauna when modeling interactions in these communities may enable us to make new predictions concerning the outcome of interactions between epibenthic predators and infaunal species.

While predatory infauna and other infaunal species have been considered collectively as prey in models of soft-bottom community structure, differences in living habits between these 2 groups may make predatory infauna more available than other infauna as prey for epibenthic predators. Most predatory infauna do not form protective tubes (exceptions include the Onuphidae and Polyodontidae). Those that have protective burrows frequently extend large portions of their bodies onto the sediment surface or leave their burrows altogether (e. g. nereids, phyllodocids) making themselves more susceptible to predation from epibenthic predators than are non-predatory infauna, many of which have protective tubes and burrows and rarely venture from them (e. g. capitellids, chaetopterids, maldanids). Shorebirds are common predators of predatory infauna (Recher, 1966; Bengtson and 
Svensson, 1968; Goss-Custard, 1977a, b; Goss-Custard et al., 1977; Schneider, 1978; Bryant, 1979; Hicklin and Smith, 1979; Kent and Day, 1983). Fishes and crabs are also important epibenthic predators (Virnstein, 1977. 1979) and both groups consume predatory infauna (Klawe and Dickie, 1957; Scarratt and Lowe, 1972; Wells and Steel, 1973; Stickney et al., 1975; Kravitz et al., 1976; Arntz, 1979; Elner, 1981; Kent and Day, 1983).

Predatory infauna may influence the abundance of other infauna by preying on adults, juveniles or larvae or by disturbing the sediment surface and reducing larval settlement and juvenile survivorship. Stomach analysis from members of 2 common predatory polychaete families, glycerids and nereids, show that they consume polychaetes, amphipods, isopods, gastropods and bivalves (Ockelmann and Vahl, 1979; Ambrose, 1982). Infaunal predatory amphipods and polychaetes have recently been shown to have a negative effect on larval settlement and juvenile survivorship (Ambrose, 1982; Commito, 1982; Oliver et al., 1982).

If predatory infauna are preferentially preyed upon by epibenthic predators or if predatory and non-predatory infauna are preyed upon equally but predatory infauna reduce the abundance of other infauna, then predatory infauna should become proportionally more abundant when epibenthic predators are excluded from the community. In this paper I test whether the ratio of the density of predatory infauna to the density of non-predatory infauna increases following the exclusion of epibenthic predators.

\section{METHODS}

I used data from 7 studies which employed cages to exclude large epibenthic predators from portions of the soft bottom (Naqvi, 1968; Young et al., 1976; Commito, 1976; Reise, 1977, 1978; Lee, 1978; Holland et al., 1980; Summerson, 1980) to test the prediction that the density ratio of predatory infauna to the remaining infauna increases following the exclusion of epibenthic predators. No attempt was made to analyze the raw data from every caging study ever conducted. The studies were chosen because they represent a broad range of habitats and because their data was accessible. A total of 56 separate exclusion experiments in 3 different habitats, sand, muddy-sand, and grass beds, were conducted in these studies. Cage artifacts (alteration of the physical and biological environment in addition to the desired exclusion of predators) are common in caging experiments in soft sediments (Virnstein, 1978). To control for cage artifacts some researchers construct cage controls, partial cages which theoretically allow free access by epibenthic predators while mimicking the effects cages have on the environment. When possible, I used the densities from cage controls to compute ratios used in the comparisons with caged areas (Lee, 1978; Summerson, 1980). In the studies where cage controls were not used (Naqvi, 1968; Young et al., 1976; Reise, 1977, 1978; Holland et al., 1980) or where cage artifacts were shown to be unimportant (Commito, 1976), data from uncaged portions of the bottom were used in the comparisons.

I excluded from the analysis all epifaunal species. The decison to exclude a species was based on information in Abbott (1974) for mollusks, Bousfield (1973) and Myers (1970) for amphipods, Fauchald and Jumars (1979) and Pettibone (1963) for polychaetes, and Barnes (1974) for other species or groups. I excluded epifaunal animals because they frequently settle on cage walls and tops and occasionally fall into cages during cleaning and sampling (Virnstein, 1978; Summerson, 1980), thereby increasing densities of some species under cages for reasons other than the exclusion of predators.

I next divided the fauna into predatory and nonpredatory species. There is considerable ambiguity regarding the exact diet of many infaunal species. Polychaetes in particular appear to possess very flexible feeding habits (Fauchald and Jumars, 1979) which undoubtedly change with age, season, habitat, and infaunal densities. Few species may be obligate predators. Occasional predatory behaviour, however, may be all that is required for these species to have a significant affect on the densities of other infaunal species. I used the review by Fauchald and Jumars (1979) to separate polychaetes which are at least occasionally predators, both carnivores and omnivores, from other feeding types. Nemerteans are entirely carnivorous preying primarily on amphipods, polychaetes and bivalves (Barnes, 1974; McDermatt, 1976; Roe, 1976). Some gastropods are infaunal and predaceous and I consulted Abbott (1974) to identify these species.

Each period of exclusion yelded 2 ratios of predatory to non-predatory infauna, 1 from the cage treatment and 1 from the uncaged control. As all experiments had at least 2 replicates for treatment and control, I used the mean density of all replicates in computing the ratios. Treating each experiment as a data point I applied a sign test (Sokal and Rohlf, 1969) to the sign of the difference in ratios between caged and uncaged areas. If no consistent difference between the ratios from the 2 areas exists then the number of times the ratio increases (positive sign) and decreases (negative sign) when epibenthic predators are excluded will be approximately equal. All differences of zero are omitted in the sign test. I employed a one-tailed test 
because the alternate hypothesis is that the ratios are greater from caged areas than from uncaged areas. Experiments were separated on the basis of habitat (sand, muddy-sand, grass) and separate analyses were done for each habitat and all habitats combined. A table of binomial probabilities was used for sand and grass habitats and the normal approximation was used for the larger samples (greater than 20) from the muddy-sand habitat and when all habitats were combined (Sokal and Rohlf, 1969).

\section{RESULTS}

Ratios of density of predatory to non-predatory infauna and sign of the difference in ratios between caged and uncaged areas are presented in Table 1. Results of the sign test show that the ratio of predatory to non-predatory infauna increased following the exclusion of epibenthic predators in muddy-sand and grass habitats (Table 2). The sign test is also significant when all habitats are analyzed together. In these cases, there was an increase in the proportion of predatory infauna when epibenthic predators were excluded. In sandy habitats the ratios of predatory to non-predatory infauna did not increase in the absence of epibenthic predators (Tables 1 and 2).

\section{DISCUSSION}

Increase in proportion of predatory infauna could be a consequence of (1) preferential predation on these predatory infauna by epibenthic predators; (2) preferential predation on predatory infauna and predation by predatory infauna on other infauna; (3) equal predation on predatory and non-predatory infauna with additional predation by predatory infauna on other infaunal species; or (4) competition between predatory and non-predatory infauna with predatory infauna outcompeting non-predatory infauna. These processes cannot be separated by comparing ratios of predatory to non-predatory infauna. Regardless of the mechanism, these results support the proposal that predatory infauna be considered separately from other infaunal species in models of soft-bottom community structure. The exclusion of epibenthic predators affects predatory and non-predatory infauna differently. Furthermore, as predators of other infauna and prey for epibenthic predators, predatory infauna may be an important link between epibenthic predators and certain infaunal species. Competition between predatory and non-predatory infauna is an unlikely explanation for the increase in the proportion of predatory infauna because Peterson (1979) showed that species richness increased and in most cases evenness increased or remained unchanged following the exclusion of epibenthic predators.

The increase in the proportion of predatory infauna following the exclusion of epibenthic predators occurred despite several factors favoring increases in the abundances of non-predatory infauna under exclusion cages. First, because cages reduce the rate of water flow they will accumulate fine sediment and arganics (Virnstein, 1978), which favor deposit-feeding species. Cage controls were used in only a few studies. While some predatory infauna may also be deposit feeders (e.g. some species of nereids; Fauchald and Jumars, 1979) and thus be attracted, other deposit-feeding species are more numerous than these predators and will probably be attracted to a greater degree. Second, the life-history characteristics of many of the nonpredatory infauna make them more likely than predatory infauna to settle and reach high densities under cages. Most predatory infauna have a more restricted reproductive period than opportunistic species whose larvae are present in the water column for large portions of the year (McCrary, 1969; Rasmussen, 1973; Grassle and Grassle, 1974). The caging studies covered all seasons of the year and no attempt was made to analyze the results by season because sample sizes would have been unacceptably small. As a result, settlement into cages is more likely for species other than predatory infauna. Opportunistic species sometimes account for the largest absolute increases under cages (Virnstein, 1979; Holland et al., 1980), a result of these species' high reproductive rates.

It is not possible to determine the reasons for the failure of predatory infauna to increase in abundance relative to the remainder of the infauna under cages in sandy habitats (Table 2). Possibilities include reduced efficiency of predatory infauna, greater efficiency of epibenthic predators in reducing the abundance of non-predatory infauna and greater cage artifacts in sand habitats compared to muddy-sand and grass habitats. Alternatively, the sample size for sandy habitats may been too small to test adequately the prediction.

Total densities of infauna in grass beds are not affected by caging (Young et al., 1976; Orth, 1977; Reise, 1977, 1978; Young and Young, 1977; Virnstein, 1978; Summerson, 1980). Orth (1977) and Reise (1977) hypothesize, and Peterson (1982) demonstrated that the dense root mat in grass beds protects infaunal organisms from predation. Many physical and biological factors may be responsible for higher infaunal densities in grass beds than in the nearby unvegetated bottom (Thayer et al., 1975, 1980; Orth, 1977; Reise, 1977). To some degree, however, grass beds may be considered as natural predator exclusion experiments 
Table 1. Source of data, ratio of density of predatory infauna to density of non-predatory infauna in samples from caged and control areas, and sign of difference in ratios between cage and control. Each pair of ratios represents 1 period of exlusion

\begin{tabular}{|c|c|c|c|c|c|c|c|}
\hline Source & $\begin{array}{c}\text { Ratio of } \\
\text { non-pres } \\
\text { Cage }\end{array}$ & $\begin{array}{l}\text { Iatory to } \\
\text { y infauna } \\
\text { Control }\end{array}$ & $\begin{array}{c}\text { Sign of } \\
\text { difference } \\
\text { Cage - Control }\end{array}$ & Source & $\begin{array}{l}\text { Ratio of } \mathrm{p} \\
\text { non-preda } \\
\text { Cage }\end{array}$ & $\begin{array}{l}\text { Aatory to } \\
\text { infauna } \\
\text { Control }\end{array}$ & $\begin{array}{c}\text { Sign of } \\
\text { difference } \\
\text { Cage - Control }\end{array}$ \\
\hline \multicolumn{4}{|c|}{ Sand } & \multicolumn{4}{|c|}{ Muddy-Sand } \\
\hline Lee (1978) & $\begin{array}{l}.146 \\
.131\end{array}$ & $\begin{array}{l}.172 \\
.145\end{array}$ & - & Reise (1977) & .001 & .002 & - \\
\hline 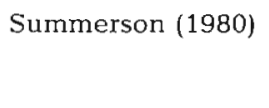 & $\begin{array}{l}114 \\
.156 \\
.356\end{array}$ & $\begin{array}{l}.159 \\
.215 \\
.269\end{array}$ & $\begin{array}{l}- \\
- \\
+\end{array}$ & $\begin{array}{l}\text { Holland et al. } \\
(1980)\end{array}$ & $\begin{array}{l}.180^{\circ} \\
.290^{\circ} \\
.068^{\circ}\end{array}$ & $\begin{array}{l}.116 \\
.018 \\
.090\end{array}$ & $\begin{array}{l}+ \\
+ \\
-\end{array}$ \\
\hline $\begin{array}{l}\text { Holland et al. } \\
\text { (1980) }\end{array}$ & $\begin{array}{l}.160 \\
.005 \\
.011 \\
.120\end{array}$ & $\begin{array}{l}.110 \\
.010 \\
.004 \\
.249\end{array}$ & $\begin{array}{l}+ \\
- \\
+ \\
-\end{array}$ & & $\begin{array}{l}.063 \\
.046 \\
.358 \\
.112\end{array}$ & $\begin{array}{l}.036 \\
.028 \\
.011 \\
.084\end{array}$ & $\begin{array}{l}+ \\
+ \\
+ \\
+\end{array}$ \\
\hline \multicolumn{4}{|c|}{ Muddy-Sand } & \multicolumn{4}{|c|}{ Grass } \\
\hline Commito (1976) & $\begin{array}{l}.443 \\
.485 \\
.567 \\
.817 \\
.151 \\
.387 \\
.282 \\
.249 \\
.182 \\
.256 \\
.257 \\
.250 \\
.104 \\
.400 \\
.048 \\
.139 \\
.308 \\
.235\end{array}$ & $\begin{array}{c}.330 \\
.444 \\
1.38 \\
.190 \\
.149 \\
.789 \\
.300 \\
.122 \\
.159 \\
.412 \\
.457 \\
.303 \\
.638 \\
.000 \\
.041 \\
.119 \\
.071 \\
.154\end{array}$ & $\begin{array}{l}+ \\
+ \\
- \\
+ \\
+ \\
- \\
- \\
+ \\
+ \\
- \\
- \\
- \\
- \\
+ \\
+ \\
+ \\
+ \\
+\end{array}$ & Young et al. (1976) & $\begin{array}{l}.075 \\
.104 \\
.085 \\
.018 \\
.309 \\
.384 \\
.277 \\
.268 \\
.309 \\
.223 \\
.165 \\
.345 \\
.015 \\
.022 \\
.004 \\
.020\end{array}$ & $\begin{array}{l}.151 \\
.357 \\
.124 \\
.355 \\
.154 \\
.056 \\
.186 \\
.407 \\
.228 \\
.223 \\
.150 \\
.187 \\
.004 \\
.005 \\
.002 \\
.004\end{array}$ & $\begin{array}{l}- \\
- \\
- \\
- \\
+ \\
+ \\
+ \\
- \\
+ \\
0 \\
+ \\
+ \\
+ \\
+ \\
+ \\
+\end{array}$ \\
\hline Reise (1978) & $\begin{array}{l}.012 \\
.014 \\
.011\end{array}$ & $\begin{array}{l}.007 \\
.014 \\
.002\end{array}$ & $\begin{array}{l}+ \\
0 \\
+\end{array}$ & Summerson (1980) & $\begin{array}{l}.251 \\
.255 \\
.420\end{array}$ & $\begin{array}{l}.096 \\
.128 \\
.397\end{array}$ & $\begin{array}{l}+ \\
+ \\
+\end{array}$ \\
\hline
\end{tabular}

Table 2. Habitat, number of experiments where the ratio of predatory to non-predatory infauna was larger from caged than control areas, total number of experiments and significance level of 1 -tailed sign test

\begin{tabular}{|c|c|c|c|}
\hline Habitat & $\begin{array}{c}\text { Number of experiments where } \\
\text { ratio is larger from caged than } \\
\text { control area }\end{array}$ & $\begin{array}{l}\text { Total number } \\
\text { of experiments }\end{array}$ & $\begin{array}{c}\text { Significance } \\
\text { level }\end{array}$ \\
\hline Sand & 3 & 9 & ns ${ }^{*}$ \\
\hline Muddy-sand & 20 & 29 & $\mathrm{p}<0.05$ \\
\hline Grass & 13 & 18 & $p<0.05$ \\
\hline All habitats & 36 & 56 & $p<0.025$ \\
\hline \multicolumn{4}{|c|}{ - ns: not significant $(p>0.05)$} \\
\hline
\end{tabular}


(Peterson, 1979) and can be predicted to have a greater proportion of predatory infauna than nearby unvegetated areas.

This prediction is true in at least 2 cases. Summerson (1980) found that $26 \%$ (by number of individuals) of the infauna in grass beds were predaceous compared to $16 \%$ in the surrounding sand. Thayer et al. (1980) found the average percentage of predatory infauna in 3 grass beds to be $48 \%$, compared to $22 \%$ in unvegetated sand. High percentages of predatory infauna are possible because of the flexible feeding habits of predatory polychaetes (Fauchald and Jumars, 1979), which make up the majority of the predatory infauna in these habitats. While predatory infauna may receive more protection in grassbeds than in unvegetated habitats, the results of comparing ratios of predatory to non-predatory infauna between caged and uncaged areas in grass beds (Table 2) indicate that predatory infauna are still being preyed upon by epibenthic predators. The greater relative abundance of predatory infauna in grass beds than in unvegetated habitats also suggests that predation by these predators on nonpredatory infauna may be a more important organizing force in vegetated habitats than in unvegetated ones.

Recent work (Reise, 1979; Ratcliffe et al., 1981; Ambrose, 1982; Commito, 1982; Oliver, et al. 1982) shows that predatory infauna are capable of reducing the abundance of other infaunal organisms. Nereis diversicolor has been shown to reduce the abundance of juvenile cockles in the field (Reise, 1979) and Macoma balthica spat in the laboratory (Ratcliffe et al., 1981). In experiments which measured colonization of sediment from which all organisms had been removed and infaunal predatory polychaetes selectively added, Commito (1982) and Ambrose (1982) found that Nereis virens reduced the abundance of a number of infaunal taxa. Oliver et al. (1982) demonstrated that several species of phoxocephalid amphipods reduce infaunal densities by predation and/or disturbance. This experimental evidence supports the contention that the increase in the proportion of predatory infauna following the exclusion of epibenthic predators was partially the result of predatory infauna reducing the abundance of other infauna.

Considering the effects of predatory infauna when modeling interactions in soft-bottom communities many help explain the paradox which exists between the results of analogous experiments in rocky intertidal and soft-bottom communities (Peterson, 1979). In the rocky intertidal, predation increases species diversity within communities by reducing competition among prey species and preventing dominant competitors from monopolizing a limiting resource and excluding other species from the community (Paine, 1966). There is no evidence for competitive exclusion by dominant species following the exclusion of predators in softbottom systems. Competitive exclusion may fail to occur following the removal of epibenthic predators either because appropriate mechanisms of interference and exploitation competition are ineffective or because densities are kept below the carrying capacity of the environment by adult-larval interactions (Peterson, 1979). These arguments are based on a view of the softbottom system composed of only epibenthic predators and infaunal prey. Exclusion experiments in the softbottom community have failed to eliminate predatory infauna and may even have caused the density of these predators to increase. Predation from predatory infauna within exclusion cages may help explain the failure of a competitive dominant to become established in response to the removal of epibenthic predators form the soft-bottom community.

I propose a 3-level interactive model for soft-sediment marine systems (Fig. 1) similar to the trophic model for lake systems. In lakes, the top trophic level is occupied by vertebrate predators (fish or salamanders), the second level by invertebrate predators (calanoid copepods and cryptic midge larvae) and the third by

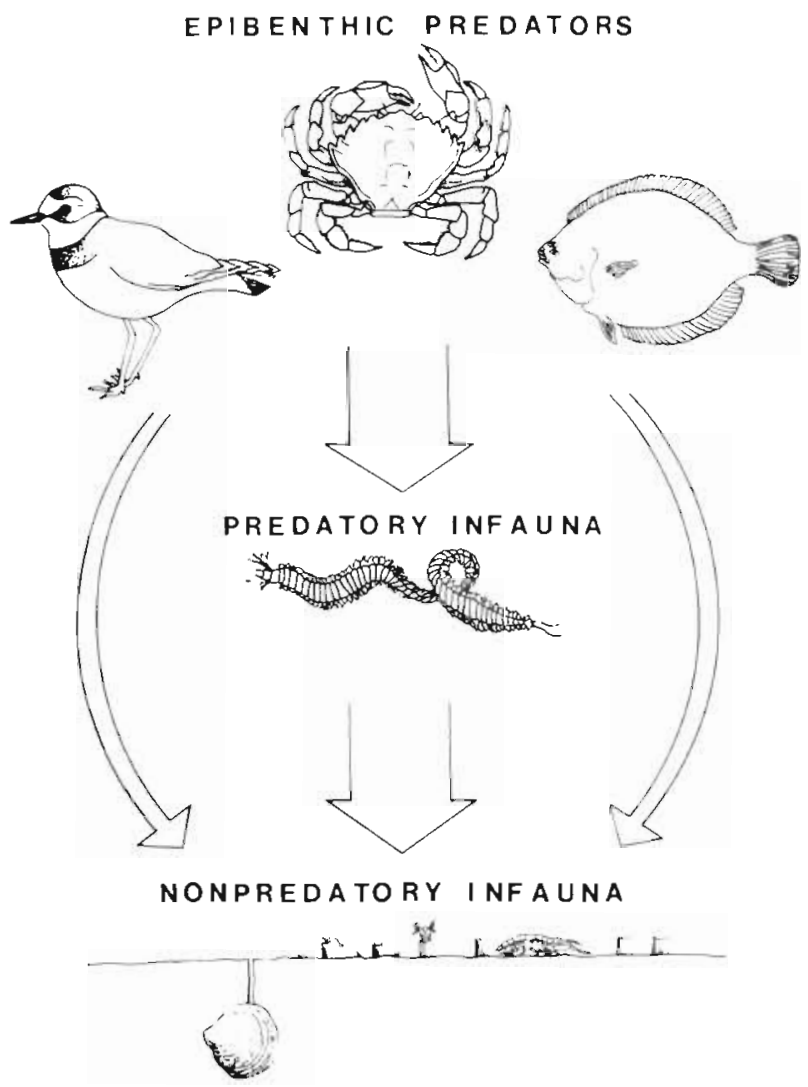

Fig. 1. Diagram of proposed 3-level interactive model. Curved arrows: interactions between epibenthic predators and nonpredatory infauna. Broad arrows: relations which may be particularly important in predicting the outcome of interactions in soft-bottom communities 
small herbivores and the jeveniles of larger hervibores (Brooks and Dodson, 1965; Dodson, 1970, 1974). In the soft-sediment marine system the mechanism of interaction between the 3 levels I propose, epibenthic predators, predatory infauna, and non-predatory infauna, may not be confined to predation. Certain epibenthic predators, such as the blue crab Callinectes sapidus and the horseshoe crab Limulus polyphemus, may be responsible for much mortality through disturbance as well as by predation. Some predatory infauna may also disturb the sediment surface during their feeding and bury newly settled larvae, juveniles, and adults. Regardless of the mechanisms of interaction between the levels, the separation of infauna into predatory and non-predatory species allows the prediction tested in this paper that predatory infauna become proportionally more abundant following the removal of epibenthic predators. The addition of predatory infauna as intermediaries between epibenthic predators and non-predatory infauna leads to the prediction, not tested here, that prey species of predatory infauna may actually be less abundant in the absence than in the presence of epibenthic predators. These predictions are impossible with the conventional model which considers only epibenthic predators and infaunal species.

Acknowledgements. I thank B. Beal, B. Duncan, M. Watzin, H. Wilson and my committee members J. Carter, J. Commito, D. Frankenberg, C. Peterson, A. Stiven and J. Sutherland for discussion and critical review of various stages of this manuscript. J. Commito, H. Lee and D. Young kindly provided original data. L. Sandöy and K. Sandöy prepared the figure. This work was supported by a doctoral dissertation research grant from the Biological Oceanography Division of NSF (OCE 79-19916), The University of North Carolina at Chapel Hill Curriculum in Marine Sciences and NSF grants OCE 77 07939 and OCE 79-09323 from the Biological Oceanography Program to C. Peterson. Support during the preparation of this inanuscript was also provided by a National Research Council Associateship with the Environmental Protection Agency and a Royal Norwegian Council for Scientific and Industrial Research postdoctoral fellowship.

\section{LITERATURE CITED}

Abbott, R. T. (1974). American seashells; the marine mollusca of the Atlantic and Pacific coasts of North America. Van Nostrand Reinhold Co., New York

Ambrose, W. G., Jr. (1982). The influence of the predatory polychaetes Glycera dibranchiata and Nereis virens on the structure of a soft-bottom community in a Maine estuary. Ph. D. thesis, University of North Carolina at Chapel Hill

Arntz, W. E. (1979). Predation by demersal fish and its impact on the dynamics of macrobenthos. In: Tenore, K. R., Coull, B. C. (ed.) Marine benthic dynamics. University of South Carolina Press, Columbia, p. 121-149

Barnes, R. D. (1974). Invertebrate zoology. W. B. Sanders Co. Philadelphia
Bengtson, S. A., Svensson, B. (1968). Feeding habits of Calidris alpina $\mathrm{L}$. and $C$. minuta in relation to the distribution of marine shore invertebrates. Oikos 19: 152-157

Bousfield, E. L. (1973). Shallow water gammaridean amphipods of New England. Cornell University Press, Ithaca

Brooks, J. L., Dodson, S. I. (1965). Predation, body size and composition of plankton. Science, N. Y. 150:28-35

Bryant, D. M. (1979). Effects of prey density and site character on estuary usage by overwintering waders (Charadrii). Estuar. coast. mar. Sci. 9:369-384

Commito, J. A. (1976). Predation, competition, life history strategies and the regulation of estuarine soft-bottom community structure. Ph. D. thesis, Duke University

Commito, J. A. (1982). The importance of predation by infaunal polychaetes in controlling the structure of a softbottom community in Maine, USA. Mar. Biol. 68: 77-81

Dodson, S. I. (1970). Complementary feeding niches sustained by size-selective predation. Limnol. Oceanogr. 15: $131-137$

Dodson, S. I. (1974). Zooplankton competition and predation an experimental test of the size-efficiency hypothesis. Ecology 55: 60.5-613

Elner, R. W. (1981). Diet of green crab Carcinus maenas (L.) from Port Herbert, southwestern Nova Scotia. J. Shellfish Res. 1: 89-94

Fauchald, K., Jumars, P. A. (1979). The diet of worms: a study of polychaete feeding guilds. Oceanogr. mar. Biol. A. Rev. 17: 193-284

Goss-Custard, J. D. (1977a). Optimal foraging and the size selection of worms by redshank, Tringa totanus, in the field. Anim. Behav. 25: 10-29

Goss-Custard, J. (1977b). The energenetics of prey selection by redshank, Tringa totanus (L.), in relation to prey density. J. Anim. Ecol. 46:1-19

Goss-Custard, J. D., Jones, R. E., Newberg, P. E. (1977). The ecology of the wash I. Distribution and diet of wading birds (Charadrii). J. appl. Ecol. 14:681-700

Grassle, J. F., Grassle, J. P. (1974). Opportunistic life histories and genetic systems in marine benthic polychaetes. J. mar. Res. 32: 253-284

Hicklin, P. W., Smith, P. C. (1979). The diets of five species of migrant shorebirds in the Bay of Fundy. Proc. Nova Scotian Inst. Sci. 29: 483-488

Holland, A. F., Mountford, N. K., Hiegal, M. H., Kaumeyer, K. R., Mihursky, J. A. (1980). Influence of predation on infaunal abundance in upper Chesapeake Bay, USA. Mar. Biol. 57: 221-235

Kent, A. C., Day, R. W. (1983). Population dynamics of an infaunal polychaete: the effect of predators and an adultrecruit interaction. J. exp. mar. Biol. Ecol. 73: 185-203

Klawe, W. L., Dickie, L. M. (1957). Biology of the blood worm Glycera dibranchiata Ehlers, and its relation to the blood worm fishery of the maritime provinces. Bull. Fish. Res. Bd Can. 115: 1-37

Kravitz, M. J., Pearcy, W. G., Guinn, M. P. (1976). Food of five species of co-occuring flatfishes on Oregon's continental shelf. Fish. Bull. U.S. 74:984-990

Lee, H. (1978). Predation and opportunism in tropical softbottom communities. Ph.D thesis, University of North Carolina at Chapel Hill

McCrary, A. B. (1969). The seasonal distribution of zooplankton in Wrightsville Sound. Ph.D. thesis, University of North Carolina at Chapel Hill

McDermatt, J. J. (1976). Predation of the razor clam Ensis directus by nemertean worm Cerebratulus lacteus. Chesapeake Sci. 17: 299-301 
Myers, A. A. (1970). Taxonomic studies on the genus Gradidierrelle coutiere (Crustaces: amphipoda), with a description of $G$. dentimera, sp. nov. Bull. mar. Sci. 20: $135-147$

Naqvi, S. M. (1968). Effects of predation on infaunal invertebrates of Alligator Harbor, Florida. Gulf Res. Rep $2: 313-321$

Ockelmann, K. W., Vahl, O. (1970). On the biology of the polychaete Glycera alba, especially its burrowing and feeding. Ophelia 8: 275-294

Oliver, J. S., Oakden, J. M., Slattery, P. N. (1982). Phoxocephalid amphipod crustaceans as predators on larvae and juveniles in marine soft-bottom communities. Mar. Ecol. Prog. Ser. 7: 179-184

Orth, R. J. (1977). The importance of sediment stability in seagrass. In: Coull, B. C. (ed.) Ecology of marine benthos. University of South Carolina press, Columbia, p. 281-300

Paine, R. T. (1966). Food web complexity and species diversity. Am. Nat. 100:65-75

Peterson, C. H. (1979). Predation, competitive exclusion and diversity in the soft-sediment communities of estuaries and lagoons. In: Livingston, R. J. (ed.) Ecological processes in coastal and marine systems. Plenum Press, New York, p. 233-264

Pettibone, M. H. (1963). Marine polychaete worms of the New England region. I. Aphroditoidea through Trochaetidae. Bull. U.S. Nat. Mus. 227: 1-356

Rasmussen, E. (1973). Systematics and ecology of the Isefford marine fauna. Ophelia 11:1-507

Ratcliffe, P. J., Jones, N. V., Walters, N. J. (1981). The survival of Macoma balthica (L.) in mobile sediments. In: Wolff, W J. (ed.) Feeding and survival strategies of estuarine organisms. Plenum Press, New York, p. 91-108

Recher, H. F. (1966). Some aspects of the ecology of migrant shorebirds. Ecology 47: 393-407

Reise, K. (1977). Predation pressure and community structure of an intertidal soft-bottom fauna. In: Keegan, B. F., Credign, P. O., Boader, P. J. S. (ed.) Biology of benthic organisms. Pergamon Press, New York, p. 513-519

Reise, K. (1978). Experiments on epibenthic predation in the Wadden sea. Helgoländer wiss. Meeresunters. 31: 55-101

Reise, K. (1979). Moderate predation on meiofauna by the macrobenthos of the Wadden Sea. Helgolander wiss. Meeresunters, 32: 453-46.5

Roe, P. (1976). Life history and predator-prey interactions of the nemertean Paranemertes peregrina Coe. Biol. Bull. mar biol. Lab., Woods Hole 150:80-106
Scarratt, D. J., Lowe, R. L. (1972). Biology of rock crab (Cancer irToratus) in Northumberland Strait. J. Fish. Res. Bd Can 29: $161-166$

Schneider, D. (1978). Selective predation and the structure of marine benthic communities. Ph.D. thesis. State Univ. of New York, Stony Brook

Sokal, R. R., Rohlf, F. J. (1969). Biometry. W. H. Freeman and Co., San Francisco

Stickney, R. R., Taylor, G. L., White, D. B. (1975). Food habits of five species of young southeastern United States estuarine Sciaenidae. Chesapeake Sci. 16: 104-114

Summerson, H. C. (1980). The effects of predation on the marine benthic invertebrate community in and around a shallow subtidal seagrass bed. M.S. thesis, University of North Carolina at Chapel Hill

Thayer, G. W., Adams, S. M., LaCroix, M. W. (1975). Structure and functional aspects of a recently established Zostera marina community. In: Cronin, L. E. (ed.) Estuarine research, Vol. 1, Chemistry, biology and the estuarine system. Academic Press, New York, p. 518-540

Thayer, G. W., Price, T. J., LaCroix, M. W. (1980), Observations on estuarine habitat utilization by juvenile and adult fish. Rep. U.S. Dept. Energy, National Marine Fishereies Service Southeastern Center

Virnstein, R. W. (1977). The importance of predation by crabs and fishes on benthic fauna in Chesapeake Bay. Ecology 58: $1199-1217$

Virnstein, R. W (1978). Predation caging experiments in soft sediments: Caution advised. In: Wiley, M. L. (ed.) Estuarine interactions. Academic Press, New York, p. $261-273$

Virnstein, R. W (1979). Predation on estuarine infauna: response patterns of component species. Estuaries 2: $69-86$

Wells, B., Steele, D. H. (1973). Intertidal feeding of winter flounder (Pseudopleuronectes americanus) in the Bay of Fundy. J. Fish. Res. Bd Can. 30:1374-1378

Young, D. K., Buzas, M. A., Young, M. W. (1976). Species densities of macrobenthos associated with seagrasses: a field experiment study of predation. J. mar. Res. 34: $577-592$

Young, D. K., Young, M. W. (1977). Community structure of the macrobenthos associated with seagrass of the Indian River estuary, Florida. In: Coull, B. C. (ed.) Ecology of the marine benthos. University of South Carolina Press, Columbia, p. 359-382 